\title{
Demineralized Bone Tissue
}

National Cancer Institute

\section{Source}

National Cancer Institute. Demineralized Bone Tissue. NCI Thesaurus. Code C133295.

Bone that has had most of the mineralized components removed while retaining collagen and noncollagenous proteins. 